\title{
Analysis of Words Related to Mistypes
}

\author{
Ryuki Komatsu a, , , Rin Hirakawa ${ }^{a}$, Hideaki Kawano ${ }^{a}$, Kenichi Nakashia, Yoshihisa Nakatoh ${ }^{a}$ \\ ${ }^{a}$ Kyushu Institute of Technology \\ 1-1, Sensui-cho, Tobata-ku, Kitakyushu-shi, Fukuoka, 804-0015, Japan \\ *nakatoh@ecs.kyutech.ac.jp
}

\begin{abstract}
In recent years, aging has become a social problem in Japan, and employment of elderly people is also increasing accordingly. About $80 \%$ of the elderly have a job with many opportunities to touch the personal computer. However, it is difficult to work for the elderly because accuracy of the operation of the personal computer is required. Therefore, we focus on the keyboard input which is the basis of personal computer operation, and are studying the correction method of mistyping which occurs at the time of input. This time, as a preliminary study for correcting mistypes, we analyzed differences between mistype words and correct input words for $10 \mathrm{~s}$ and $20 \mathrm{~s}$ people accustomed to personal computer operation. As result for analysis of correct input words, it is found that ' $\mathrm{k}$ $+\operatorname{vowel}(\mathrm{a}, \mathrm{i}, \mathrm{u}, \mathrm{e}, \mathrm{o})$ ' frequently continues twice in a row. And as result for analysis of mistyped words, it is found that the characters have many voiced sounds and semi-voiced sounds such as 'ga(が)', 'do(ど)' and 'pa(ぱ)'.
\end{abstract}

Keywords: Hardware Keyboard, Personal computer, Typing mistake, User interface, Ergonomics.

\section{Introduction}

In recent years, the aging has become a social problem in Japan, and the employment of elderly people is also increasing accordingly. Fig.1 shows that production age population rate is decreasing and aging rate is increasing in Japan $^{(1)}$. Also, Fig. 2 shows that $80 \%$ of the occupations in which elderly people are employed are technical and professional, management or office work, and there are many opportunities to operate personal computers ${ }^{(2)}$. Moreover, Fig.3 shows that the personal computer ownership rate of household head age 65 years old or more is much higher than $50 \%{ }^{(3)}$. However, for elderly people, personal computers are difficult to operate and need to be easy to use. Therefore, in this study, as a preliminary study for correcting mistyping, we analyze differences between mistype words and correct input words for $10 \mathrm{~s}$ and $20 \mathrm{~s}$ people who are familiar with personal computers.

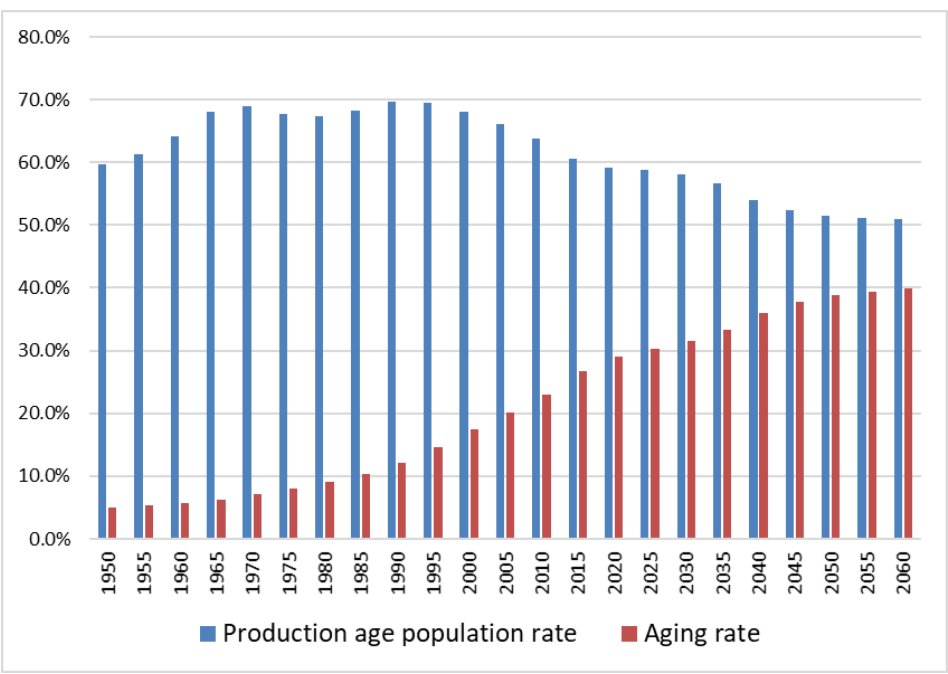

Fig. 1. Transition of population rate in Japan

Technical and Proffessional work

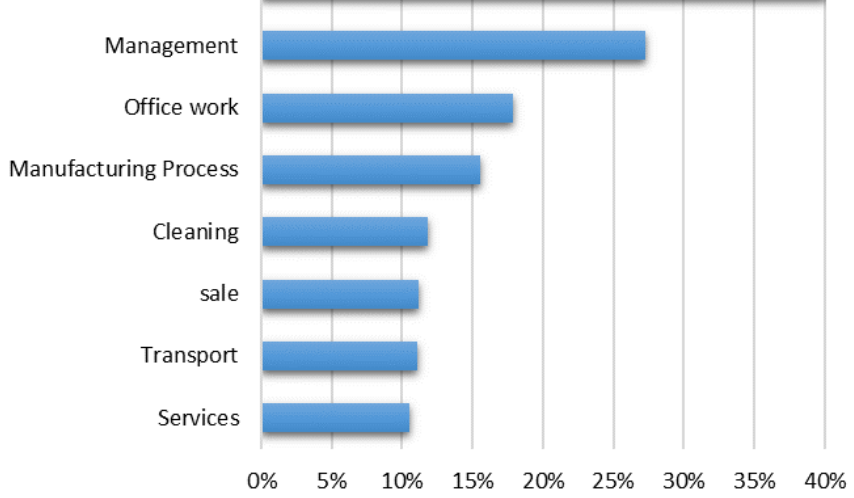

Fig. 2. Work of elderly people 


\section{Classification of Mistype}

As an analysis method of mistyping, divide the pattern of input errors into $\operatorname{six}^{(4)}$. Table 1 is an example of each input error. A detailed explanation of each mistake is described below.

(a) Replacement

The first one is "Replacement". Replacement is that you press another key when you must press correct key. Looking at an example, you can see that " $U$ " is input where "I" must be input.

\section{(b) Removal}

The second is "Removal". Removal means that characters what must be input are not input. Looking at an example, you can see that there is not one ' $\mathrm{N}$ '.

\section{(c) Exchange}

The third one is "Exchange". exchange is to press next key earlier than the key what must be typed ahead when entering a character string. Looking at an example, you can see that the locations of ' $\mathrm{C}$ ' and ' $\mathrm{H}$ ' are interchanged.

\section{(d) Insertion}

The fourth one is "Insertion". Insertion is that inappropriate characters get into the correct character string. In addition, there are two types of insertion, "involvement" and "Repetition".

\section{(e) Involvement}

The fifth one is "Involvement". Involvement is that you press also the adjacent key when you input the appropriate key. The involvement belongs to the type of "Insertion". Looking at an example, you can see that 'O' next to 'I' is unnecessarily entered.

\section{(f) Repetition}

The sixth is "Repetition". Repetition is to push the same key unnecessarily twice or more in succession. Repetition belongs to the type of "Insertion". Looking at an example, you can see that $\mathrm{N}$ has been entered more than once.

Generally, typing errors can be classified by the above six types, but if there are mistakes not belonging to six types, these belong to the type that seems to be the closest.

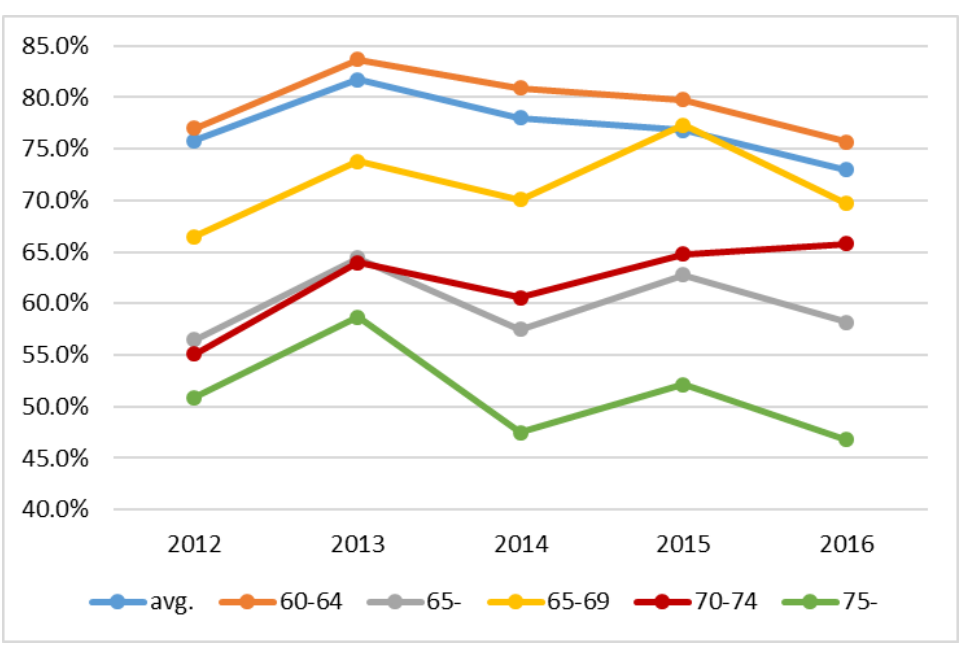

Fig. 3. Transition of PC ownership rate in Japan

Table 1. Example of mistyping

\begin{tabular}{|c|c|}
\hline Type of Miss & e.g.:KONNNICHIHA(こんにちは) \\
\hline Replacement & KONNNUCHIHA(こんぬちは) \\
\hline Removal & KONNICHIHA(こんいちは) \\
\hline Exchange & KONNNIHCIHA(こんに h しは) \\
\hline \multicolumn{2}{|c|}{ 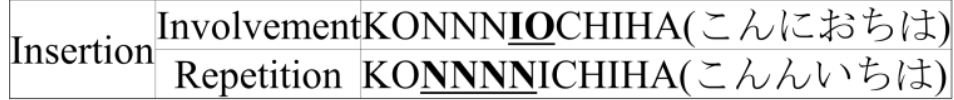 } \\
\hline
\end{tabular}

\section{Evaluation of Experimentation}

We conducted an experiment and analyze differences between mistype words and correct input words with using the above classification method. Experimental conditions and experimental results are as follows.

\subsection{Experimental Condition}

The experimental procedure is shown in Fig. 4. First, the subject inputs the displayed word. Next, the subject presses enter. At that moment, proceed to next input if the input word is correct. But input same displayed word again if the input word is incorrect.

We ask subject people who are 10 s and 20 s to input 100 words per experiment as described above. In order to have natural input, it is permitted that using the delete operation (BackSpace) of characters and checking the keyboard. Also, when experimenting, we measure the time in order to cause mistakes and made them conscious to have them input as quickly as possible. In this time, input style is hiragana. This is to eliminate the conversion error. About 3000 words such as verbs, adjectives, and nouns are prepared for the experiment, and 100 words are input at random each time. 


\subsection{Experimental Result}

The number of experiments is about 320 times.Fig. 5 shows the experimental results for number of correct input words and Fig. 6 shows the experimental results for number of mistype words. The total number of correct input words was about 25,000 , and the total number of mistype words was about 7,500.

Table 2 shows the top 10 words of correct input and mistyped, and their number. The word input the most correctly was 'kakeru'.And the most mistyped words were 'hogaraka' and 'toiawaseru'.

The common feature of the correct input words is that the number of characters is small. Also, the correct words often have feature that ' $\mathrm{k}+\operatorname{vowel}(\mathrm{a}, \mathrm{i}, \mathrm{u}, \mathrm{e}, \mathrm{o})$ ' continues twice in a row. It is assumed that pressing the same consonant key reduces the frequency that finger moves to the other keys and the chance of making mistakes. Moreover, the character of correct input words is frequently used, when we input Japanese. It is assumed that sequence of character that we are used to input also reduces making mistakes.

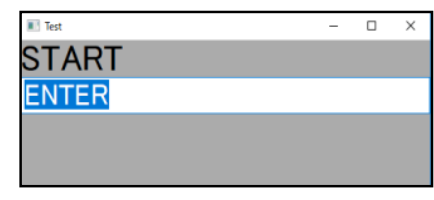

Press Enter

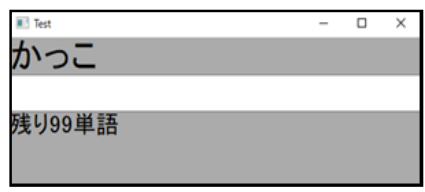

Correct Input
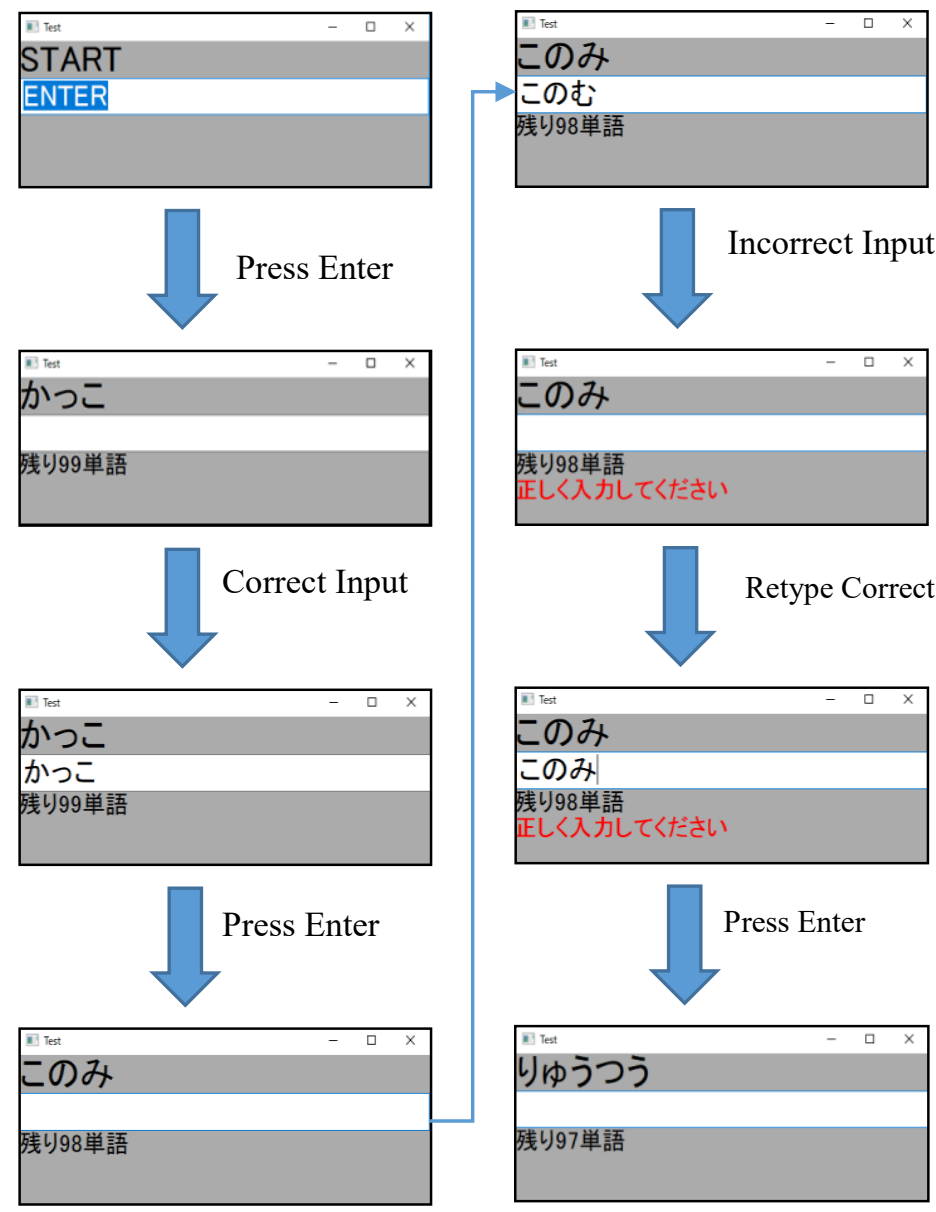

Retype Correctly

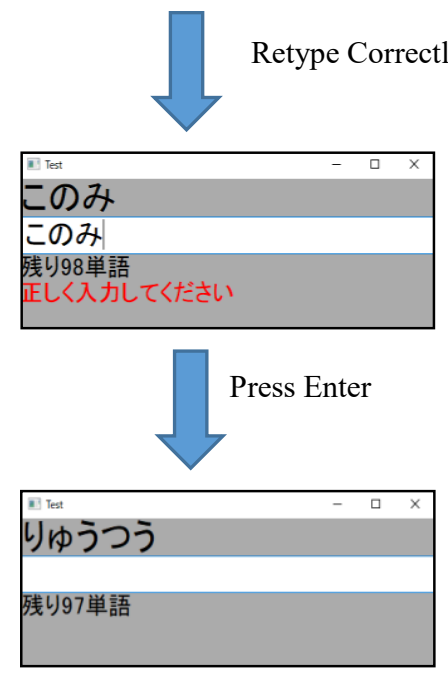

Fig. 4. Experiment procedure
The common feature of the mistype words is that the number of characters is much than the number of characters of correct input words and these characters have many voiced sounds such as 'ga(が)', 'do(ど)', and semi-voiced sounds such as 'pa(ぱ)'. It is assumed that long words cause mistake, and unvoiced sound is frecqently input incorrectly when the characters of voiced and semi-voiced sound must be input (ex. 'ga/が'ヤ'ka/か', 'do/ど'ヤ'to/と'). Moreover, it is assumed that it causes mistakes easily because 'Toiawaseru' is input with ring finger and little finger of left hand in succession.

Fig. 7 shows the results of mistype classification of top 10 words. "Replacement" was the most input error. In particular, replacement such as "G" and "H","R" and "T" occurred frequently because it is used frequently in Japanese input and the key arrangement is next to each other.

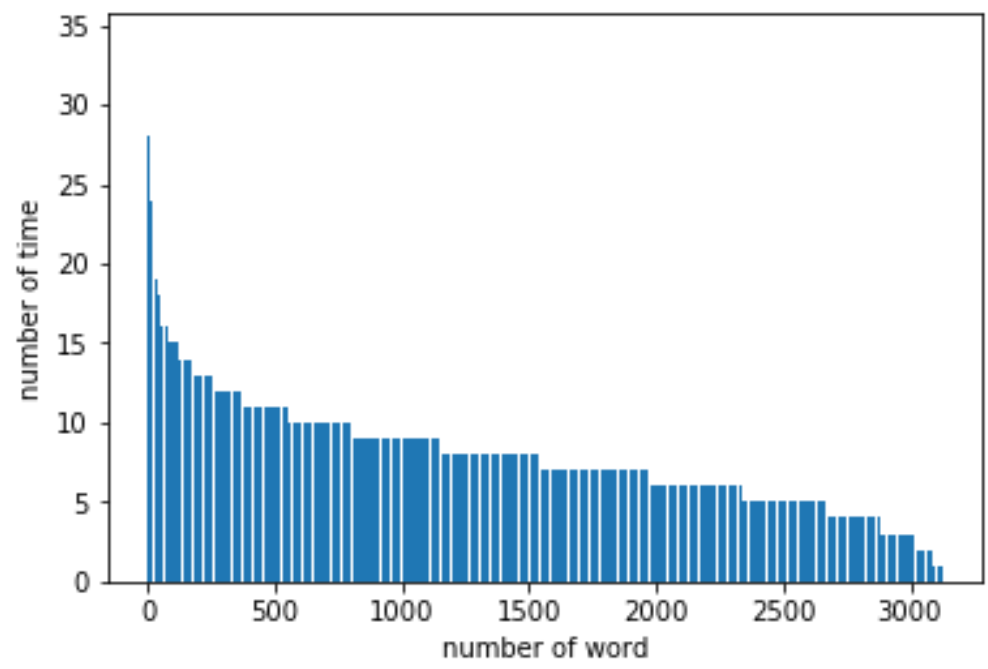

Fig. 5. Correct input words

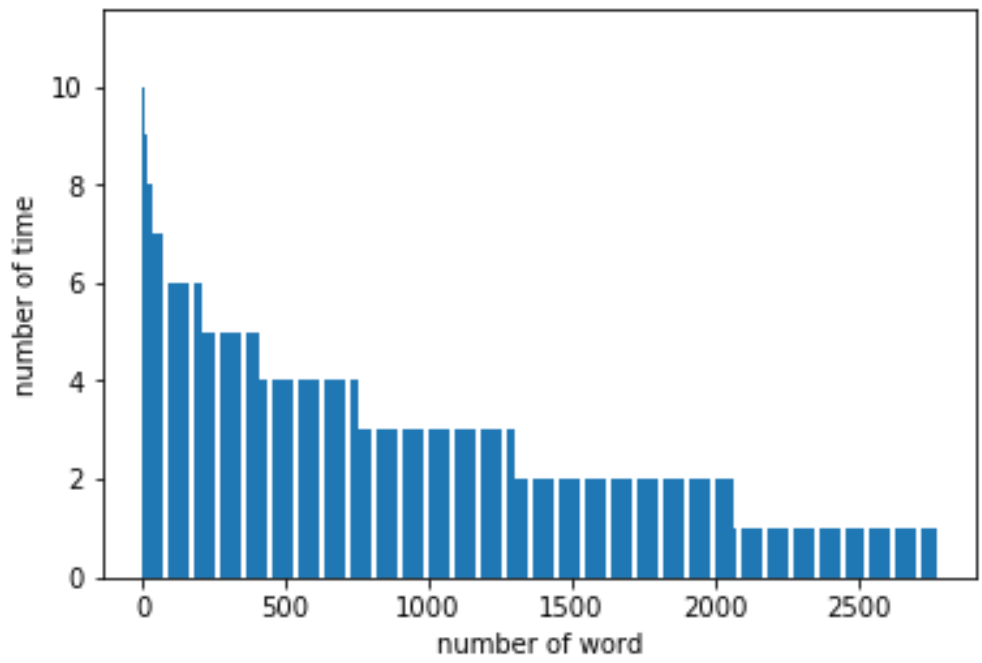

Fig. 6. Mistype words 
Fig.8 shows the results of mistype classification of 'Insertion' . "Involvement" and 'Repetition' was 15.7\% and $12.9 \%$.In particular, it was found that ' $G$ ' and ' $H$ ', 'R' and 'E' are frequently input about "Involvement".

\section{Conclusions}

In this study, we were able to find out what words were easy to mistype and, conversely, what words be typed correctly, and what their common feature is.

The future task is to conduct experiments, collect data, and analyze data for elderly people. When we experimented in elderly people, it is assumed that different tendency is seen with young people. And we plan to experiment with increasing the number of words.

\section{References}

(1) Ministry of Internal Affairs and Communications, "WHITE PAPER Information and Communications in Japan"(2016 edition)

(2) The Japan Institute for Labour Policy and Traning, " Survey on Employment of Elderly People"

(3) Ministry of Internal Affairs and Communications, Communications Usage Trend Survey (28th Report)

(4) Yuzo Noda, " Investigation of MISTYPE ts analysis", The 47th Information Processing Society of Japan
Table 2. Correct input and mistype words

\begin{tabular}{|c|c|c|c|}
\hline Correct Input Words & $\begin{array}{c}\text { Number } \\
\text { of time }\end{array}$ & Mistype Words & $\begin{array}{l}\text { Number } \\
\text { of time }\end{array}$ \\
\hline $\begin{array}{l}\text { Kakeru } \\
\text { (かける) }\end{array}$ & 34 & $\begin{array}{l}\text { Hogaraka } \\
\text { (ほがらか) }\end{array}$ & 11 \\
\hline $\begin{array}{l}\text { Seikaku } \\
\text { (せいかく) }\end{array}$ & 30 & $\begin{array}{l}\text { Toiawaseru } \\
\text { (といあわせる) }\end{array}$ & 11 \\
\hline $\begin{array}{l}\text { Maku } \\
(\text { まく) }\end{array}$ & 29 & $\begin{array}{l}\text { Hottodoggu } \\
\text { (ほっとどっぐ) }\end{array}$ & 10 \\
\hline $\begin{array}{l}\text { Wariai } \\
\text { (わりあい) }\end{array}$ & 28 & $\begin{array}{l}\text { Jouhougijutsu } \\
\text { (じょうほうぎじゅつ) }\end{array}$ & 10 \\
\hline $\begin{array}{l}\text { Mottomo } \\
(も つ と も)\end{array}$ & 27 & $\begin{array}{l}\text { Mottomo } \\
(も っ と も)\end{array}$ & 10 \\
\hline $\begin{array}{l}\text { Shibou } \\
\text { (しぼう) }\end{array}$ & 27 & $\begin{array}{l}\text { Neduyoi } \\
\text { (ねづよい) }\end{array}$ & 9 \\
\hline $\begin{array}{l}\text { Kakou } \\
\text { (かこう) }\end{array}$ & 27 & $\begin{array}{l}\text { Supagethi } \\
\text { (すぱげてい) }\end{array}$ & 9 \\
\hline $\begin{array}{l}\text { Kekkou } \\
\text { (けっこう) }\end{array}$ & 26 & $\begin{array}{l}\text { Tsutawaru } \\
\text { (つたわる) }\end{array}$ & 9 \\
\hline $\begin{array}{l}\text { Shinnkoku } \\
(し ん こ く)\end{array}$ & 25 & $\begin{array}{l}\text { Hosonagai } \\
\text { (ほそながい) }\end{array}$ & 9 \\
\hline $\begin{array}{l}\text { Nobasu } \\
\text { (のばす) }\end{array}$ & 25 & $\begin{array}{l}\text { Tyoukikann } \\
\text { (ちょうきかん) }\end{array}$ & 9 \\
\hline
\end{tabular}

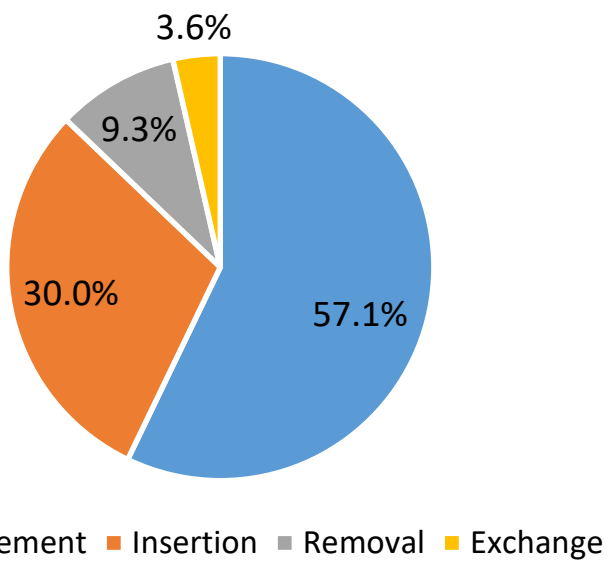

- Replacement $\square$ Insertion $\square$ Removal $\square$ Exchange

Fig. 7. Analysis of mistype classification (top 10)

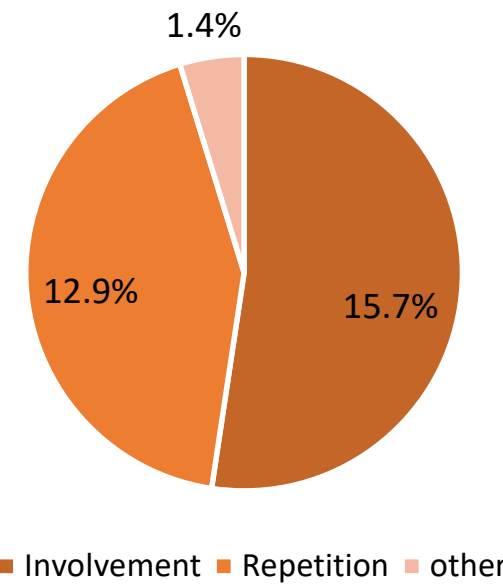

Fig. 8. Analysis of mistype classification (Insertion) 